\title{
Modulatory Role of Gallic Acid and Vitamin $C$ on Amoxicillin/Clavulanic Acid Combination Induced Hepatotoxicity in Adult Albino Rats
}

\author{
Asmaa Y. A. Hussein ${ }^{1 *}$, Sania K. Elwia ${ }^{2}$, Shaymaa M. Abd El Rahman ${ }^{2}$, Haidy M. Fakher ${ }^{1 *}$
}

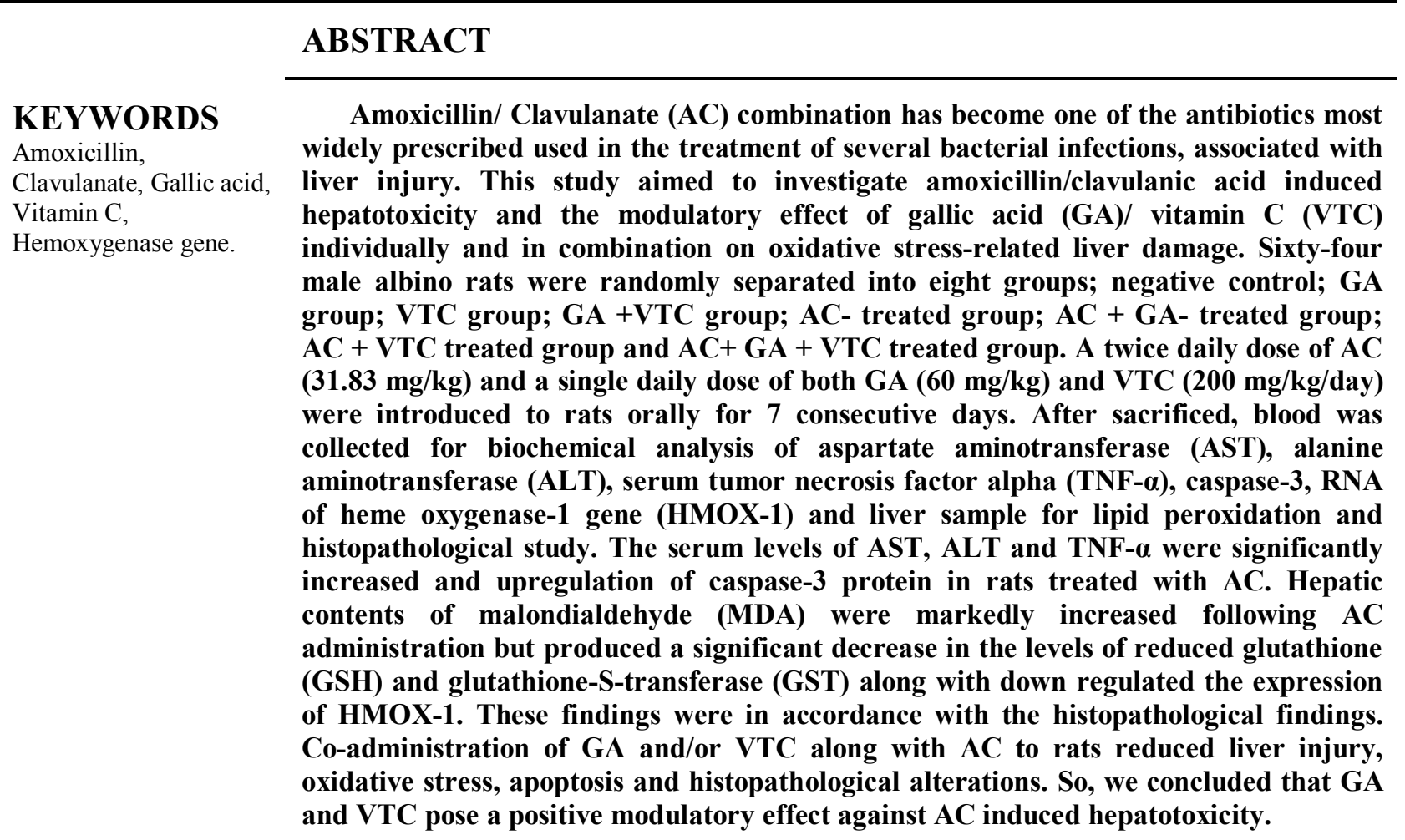

\section{Introduction}

Drug-induced liver injury is becoming popular around the world. Antibiotics are known as one of the causes of liver injury, due to its high exposure rate (Leitner et al., 2010; Devarbhavi and Andrade, 2014).

\footnotetext{
$\overline{.(1)}$ Forensic Medicine \& Clinical Toxicology Department, Faculty of Medicine, Banha University, Egypt.

${ }^{(2)}$ Biochemistry Department, Faculty of Medicine, Banha University, Egypt.

E-mail: asmaa.hussein@fmed.bu.edu.eg aafakher@gmail.com
}

Amoxicillin/clavulanic acid (AC) is an oral Broad-spectrum antibacterial compound composite of an antibiotic semi-synthetic penicillin (amoxicillin) and an inhibitor of $\beta$ lactamase (potassium clavulanate) (Fig. 1). It has been effectively used for over 20 years in the treatment of various bacterial infections (White et al., 2004; Olayinka and Olukowade, 2010). 


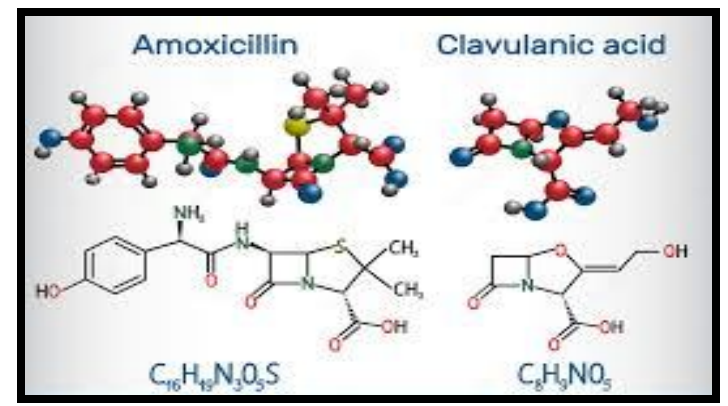

Fig. (1): Chemical structure of amoxicillin/clavulanic acid (Olayinka et al., 2012).

Although AC has become one of the antibiotics most commonly prescribed, the administration of the drug might be correlated with cholestatic and hepatocellular liver injury, which appeared to be primarily due to the clavulanate component (Stine and Chalasani, 2015; Yu et al., 2017a).

Hemeoxygenase (HO) in the heme degradation pathway is a rate-limiting enzyme. Many compounds such as metal ions and heme compounds are produced in animal tissues, especially the liver. Oxidant species have a vital role in the production of heme oxygenase gene by direct action or by consumption of GSH. Increased activity of heme oxygenase will enhance unconjugated bilirubin formation which known a biological buffer against oxidative stress in the liver and a reactive oxygen species (ROS) effective scavenger (Guillermo et al., 2000).

Gallic acid (3,4,5-trihydroxybenzoic acid, GA) is a polyphenolic substance extracted naturally from plants in particular green tea, grapes, various berries and popularly used in food, drugs and cosmetic products. It has been received great attention because of it has been proven to possess powerful antioxidant properties of the diminution reactive oxygen species (ROS), such as superoxide anions, hydrogen peroxide, hydroxyl radicals and hypochlorous acid (Priscilla and Prince, 2009; Chaphalkar et al., 2017).
Vitamin C (ascorbic acid, VTC) is an antioxidant vitamin soluble in water present in the diet which representing essential cofactor for many enzymes involved in different biochemical functions and acts as a reducing agent or an electron donor. The adverse effect of reactive oxygen and nitrogen species is significantly reduced, which can induce oxidative damage to macromolecules like those of lipids, proteins and DNA. It is also capable of scavenging/neutralizing singlet oxygen, hydroxyl, superoxide and water soluble peroxyl radical (Jacob and Sotoudeh, 2002; Seghrouchni et al., 2002).

The current work was planned to assess the scavenging antioxidative bioactivities of gallic acid /vitamin $\mathrm{C}$ and synergistic modulatory effect of both on oxidative stressrelated injury of liver in experimental rats poisoned with amoxicillin/clavulanic acid.

\section{Material and Methods}

\section{Chemicals:}

Augmentin $625 \mathrm{mg}$ (a combination of Amoxicillin/clavulanic acid) was purchased from a local pharmacy in the form of filmcoated tablets manufactured by GlaxoSmithKline Egypt). Gallic acid white powder of purity $\geq 98.5 \%$ was purchased from Sigma-Aldrich Chemical Co. (USA). Vitamin C powder $(100 \%)$ purity was purchased from El-Gomhureia pharmaceutical and chemical company, Cairo, Egypt. All other chemical reagents used were analytical grades and were prepared freshly prior to each experiment.

\section{Dosage regimen and vehicle:}

All drugs were taken for seven consecutive days, orally via appropriate gastric tube. Amoxicillin/ Clavulanate (Augmentin $625 \mathrm{mg}$ ) tablets were ground into a powder, dissolved in distilled water resulting in a suspension and it was administered at a dose 
represented the human therapeutic dose of (31.83 $\mathrm{mg} / \mathrm{kg} /$ twice daily) according to (Olayinka and Olukowade, 2010).

Gallic acid was dissolved in distilled water at a dose of $(60 \mathrm{mg} / \mathrm{Kg} /$ day $)$ according to (Omobowale et al., 2017).

Vitamin $\mathrm{C}$ was dissolved in distilled water at a dose of $(200 \mathrm{mg} / \mathrm{kg} /$ day $)$ according to (Farombi and Onyema, 2006).

\section{Experimental animals:}

Sixty-four (64) adult healthy male albino rats weighing 200-220 g were received from Helwan farm (animal house of the Biological Products and Vaccines; VASERA, Giza, Egypt). Rats were left for one week for acclimatization prior to starting the experiment. All care and procedures adopted for the current study were according to the approval of the animal ethics committee of Scientific Research, Faculty of Medicine, Banha University, Egypt.

\section{Experimental design and treatments:}

Rats were separated randomly into eight equal groups of (eight per each) as follows: Group a (negative control): Only treated with distilled water till the end of the experiment to measure the basic parameters. Group b (GA-treated): treated with GA. Group $c$ (VTC-treated): treated with VTC. Group $d$ (GA + VTC- treated). Group e (AC- treated): was received AC. Group $f$ (AC + GA- treated). Group $g$ (AC + VTC- treated). Group $h$ (AC + GA + VTC- treated).

\section{Sampling:}

\section{a. Serum samples:}

The rats after 24 hours of last treatment were anaesthetized and sacrificed. Blood was collected from abdominal aorta in two tubes; one to separate serum for biochemical analysis of (aspartate aminotransferase (AST), alanine aminotransferase (ALT), serum tumor necrosis factor alpha (TNF- $\alpha$ ) and caspase- 3 ). The other tube was used to determine RNA of heme oxygenase-1 gene (HMOX-1).

\section{b. Tissue samples:}

The liver was quickly removed after scarification, washed with ice cold physiological saline and sectioned into two parts; the first one was stored at $-20{ }^{\circ} \mathrm{C}$. Later, the homogenate was centrifuged at $4000 \mathrm{rpm}$ for $5 \mathrm{~min}$ at $40{ }^{\circ} \mathrm{C}$ to separate the supernatant which was utilized for estimation of malondialdehyde (MDA), reduced glutathione (GSH) and glutathione -S- transferase (GST). The other part from hepatic tissue was used for histopathological samples.

\section{Methods:}

\section{a.Determination of Liver function parameters (serum AST and ALT):}

They were estimated spectrophotometrically using commercial test kits of (AST and ALT) supplied by Diamond Diagnostics. The level of both (AST and ALT) was expressed as (U/L).

\section{b. Determination of serum tumor necrosis factor alpha (TNF- $\alpha$ ) and caspase 3:}

They were estimated by enzyme-linked immunosorbent assay (ELISA Rat TNF- $\alpha$ and caspase-3 Immunoassay kits) manufactured by Orgenium, Helsinki, USA. Their levels were expressed as (pg/ml).

\section{c. Determination of liver lipid peroxidation / antioxidant parameters:}

Malondialdehyde (MDA), reduced glutathione (GSH) and glutathione -Stransferase (GST) were measured using a colorimetric method (Bio diagnostics, Dokki, 
Giza, Egypt) and were expressed as (nmol $\mathrm{MDA} / \mathrm{g}$ tissue, $\mathrm{mg} / \mathrm{g}$ and $\mathrm{U} / \mathrm{g}$ respectively).

\section{d. Analysis of RNA for expression of heme oxygenase-1 gene (HMOX-1):}

Expression of HMOX-1 was analyzed by real time-PCR. Total RNA was extracted from serum by using RNA Mini Kit (Qiagen, USA) where the quantity and quality of RNA were evaluated by nano drop (USA) ratio of readings at 260 and $280 \mathrm{~nm}(\mathrm{~A} 260 / 280)$ to detect the purity of RNA. RNA had a 280/260 ratio of 1.9-2.3 (OD260/OD280).

\section{Reverse transcription - quantitative polymerase chain reaction ( $R T-q P C R)$}

RNA $(5 \mu \mathrm{g})$ was then reversed by using the first cDNA synthesis kit of the revert aid TM (Ferments life science, USA) then cDNA was subsequently amplified with the Syber Green PCR Master Kit (Applied Biosystems, USA) in a 48-well plate, PCR was conducted in a $30 \mu$ reaction volume containing $5 \mu 1$ lcDNA, $2.5 \mu$ l forward primers, $2.5 \mu 1$ reverse primers, the following sequences have been designed Hmox-1, 5-ATA GAG CGA AAC AAG CAG A-3 and 5-TAG AGC TGT TTG AAC TTG G-3GAPDH was used as an internal control and sequence of primers was: forward CAGTGCCAGCCTCGTCTCAT and reverse AGGGGCCATCCACAGTCT TC. $5 \mu \mathrm{l}$ of DNA polymerase, $7.5 \mu$ syber green and $7.5 \mu$ buffer. By using one step real time PCR instrument (Applied Bio systems, USA), PCR amplification were done as follows: initial denaturation at $94{ }^{\circ} \mathrm{C}$ for $5 \mathrm{~min}$, then by at 94 ${ }^{\circ} \mathrm{C} 30 \mathrm{~s}, 35 \mathrm{~s}$ at $54{ }^{\circ} \mathrm{C}$, and $2 \mathrm{~min}$ at $72{ }^{\circ} \mathrm{C}$ for a total of 35 cycles and terminal extension at 72 ${ }^{\circ} \mathrm{C}$ for 10 minutes.

Relative quantification of Hmox-1 was done with the 2-ddCt method, and analyzed by ABI prism 7500 the Boxplot software and values were normalized to the quantity of GAPDH.

\section{e. Histopathological evaluation of the liver:}

The liver samples were preserved in neutral buffered formalin (10\%) solution for fixation and included in bars of paraffin, then sliced at 4-6 microns' thickness, then stained by using Hematoxylin and Eosin (H\&E) according to (Bancroft and Layton, 2019).

\section{Statistical analysis}

The data was analyzed using SPSS statistical software (20.0; SPSS Inc., Chicago, IL). Kruskal- Wallis was used for multiple comparisons of quantitative variables and ManWhitney test was applied for the comparison of quantitative variables after establishing their non-normality by K-S test of normality. ANOVA test was used for comparing means of the parametric values by using post hoc test (LSD) for multiple comparisons. Significant differences are found at $p \leq .05$.

\section{Results}

All the studied biochemical parameters of negative control, GA-treated, VTC-treated and "GA + VTC"-treated groups showed non statistically significant differences $(p>0.05)$ between them as shown in (Table 1). So the negative control group was chosen as a representative group to be compared with the biochemical results of the other treated groups.

In the current study, the administration of $\mathrm{AC}$ orally alone caused a highly significant increase in the mean values of blood (AST, ALT, TNF- $\alpha$ and caspase 3) and hepatic tissue (MDA) along with a significant reduction of hepatic GSH and GST. Furthermore, there was significant down regulation in HMOX-1 gene as compared with control groups. The highest elevated and reduced values of previously measured parameters were recorded in ACtreated group as shown in (Tables 1 and 2). 
However, treatment with GA and/or VTC along with $\mathrm{AC}$ for the same period in "AC+ GA-treated", "AC + VTC"-treated and "AC + GA + VTC"-treated groups led to significant reduction in the elevated serum levels of measured liver injury biomarkers (AST, ALT, TNF- $\alpha$, caspase 3 ) and hepatic tissue (MDA), as well as significant improvement in hepatprotector indices (GSH and GST) in addition to upregulation of (HMOX-1 gene) as compared to AC-treated groups alone as shown in (Tables 1 and 2).

Moreover, the previously measured parameters illustrate significant improvement when GA and VTC used together in ("AC + GA + VTC"-treated group) as compared to (AC-treated, "AC + GA-treated" and "AC + VTC"-treated) groups with exception of (AST and caspase-3) where the improvement was insignificant as shown in (Tables 1 and 2).

Table (1): Statistical comparison among the studied groups as regard AST, ALT, caspase-3 and TNF- $\alpha$.

\begin{tabular}{|c|c|c|c|c|}
\hline & $\begin{array}{c}\operatorname{AST}(\mathrm{U} / \mathrm{L}) \\
\operatorname{Median}(\mathrm{IQR}) \\
\end{array}$ & $\begin{array}{c}\text { ALT(U/L) } \\
\text { Median (IQR) }\end{array}$ & $\begin{array}{c}\text { TNF(pg/ml) } \\
\text { Median (IQR) }\end{array}$ & $\begin{array}{c}\text { Caspase-3(pg/ml) } \\
\text { Median (IQR) }\end{array}$ \\
\hline Control group & $\begin{array}{c}160 \\
(159-160.75) \\
\end{array}$ & $\begin{array}{c}47 \\
(44.5-48.75) \\
\end{array}$ & $\begin{array}{c}4 \\
(2.25-5) \\
\end{array}$ & $\begin{array}{c}0.7 \\
(0.53-0.9)\end{array}$ \\
\hline GA group & $\begin{array}{c}159.5 \\
(157.25-161.75) \\
\end{array}$ & $\begin{array}{c}46.5 \\
(45-48.75) \\
\end{array}$ & $\begin{array}{c}3.5 \\
(2.25-4.75) \\
\end{array}$ & $\begin{array}{c}0.75 \\
(0.55-0.98) \\
\end{array}$ \\
\hline VTC group & $\begin{array}{c}159.5 \\
(155.75-161.5)\end{array}$ & $\begin{array}{c}45.5 \\
(44.25-50.5) \\
\end{array}$ & $\begin{array}{c}4 \\
(2.25-4.75) \\
\end{array}$ & $\begin{array}{c}0.75 \\
(0.63-0.9) \\
\end{array}$ \\
\hline GA + VTC group & $\begin{array}{c}159.5 \\
(158.25-160) \\
\end{array}$ & $\begin{array}{c}47 \\
(45.5-49.75) \\
\end{array}$ & $\begin{array}{c}4 \\
(3.25-5) \\
\end{array}$ & $\begin{array}{c}0.65 \\
(0.43-1.03) \\
\end{array}$ \\
\hline AC group & $\begin{array}{c}411^{\text {abcd }} \\
(408-414.75)\end{array}$ & $\begin{array}{c}81.5^{\mathrm{abcd}} \\
(78.5-84.5)\end{array}$ & $\begin{array}{c}164^{\mathrm{abcd}} \\
(152.5-173.25)\end{array}$ & $\begin{array}{c}10^{\text {abcd }} \\
(8-11.75)\end{array}$ \\
\hline AC+ GA group & $\begin{array}{c}315.5^{\text {abcde }} \\
(289.75-318.75) \\
\end{array}$ & $\begin{array}{c}54^{\text {abcde }} \\
(50.25-65.75) \\
\end{array}$ & $\begin{array}{c}57.5^{\text {abcde }} \\
(37.25-66.5) \\
\end{array}$ & $\begin{array}{c}2.5^{\text {abcde }} \\
(2-4) \\
\end{array}$ \\
\hline VTC + AC group & $\begin{array}{c}314^{\text {abcde }} \\
(220.5-320.25) \\
\end{array}$ & $\begin{array}{c}58^{\text {abcde }} \\
(55.25-62.5) \\
\end{array}$ & $\begin{array}{c}58^{\text {abcde }} \\
(37.25-64.75) \\
\end{array}$ & $\begin{array}{c}3^{\text {abcde }} \\
(1.05-5.5) \\
\end{array}$ \\
\hline $\begin{array}{l}\text { GA + Vit C+ AC } \\
\text { group }\end{array}$ & $\begin{array}{c}307^{\text {abcde }} \\
(234.75-315.75) \\
\end{array}$ & $\begin{array}{c}48^{\text {efg }} \\
(45.5-52.5) \\
\end{array}$ & $\begin{array}{c}17.5^{\text {abcdefg }} \\
(10-23.5) \\
\end{array}$ & $\begin{array}{c}2^{\text {abcde }} \\
(1.13-3.75) \\
\end{array}$ \\
\hline KW Test & 43.05 & 41.89 & 54.44 & 48.73 \\
\hline p value & $<0.001 * *$ & $<0.001 * *$ & $<0.001 * *$ & $<0.001^{* *}$ \\
\hline
\end{tabular}

$(* *)$ = Highly significant; $\mathrm{IQR}=$ Inter Quartile Range; KW: Kruskal-Wallis test; $\mathrm{GA}=$ gallic acid ; VTC $=$ vitamin $\mathrm{C} ; \mathrm{AC}=$ Amoxicillin/clavulanic acid ; AST $=$ Aspartate aminotransferase; ALT $=$ Alanine aminotransferase; $\mathrm{TNF}-\alpha=$ tumour necrosis factor alpha; Different letter within the same row indicates significant differences $(p<0.05)$ between experimental groups for the same blood and tissue chemical parameter; ${ }^{a} \rightarrow$ difference versus control group; ${ }^{b} \rightarrow$ difference versus GA group; ${ }^{\mathrm{c}} \rightarrow$ difference versus VTC group; ${ }^{\mathrm{d}} \rightarrow$ difference versus GA + VTC group; ${ }^{\mathrm{e}} \rightarrow$ difference versus AC group; $\stackrel{\mathrm{f}}{\rightarrow}$ difference versus AC + GA group; $\stackrel{\mathrm{g}}{\rightarrow}$ difference versus AC. 
Table (2): Statistical comparison among the studied groups as regard MDA, GSH, GST, and Hemeoxygenase gene expression:

\begin{tabular}{|c|c|c|c|c|}
\hline & $\begin{array}{c}\text { Tissue MDA } \\
\text { Median (IQR) }\end{array}$ & $\begin{array}{r}\text { Tissue GSH } \\
(\text { mean } \pm \text { SD) } \\
\end{array}$ & $\begin{array}{c}\text { Tissue GST } \\
(\text { mean } \pm \text { SD) }\end{array}$ & $\begin{array}{c}\text { Heme-oxygenase } \\
\text { Median (IQR) }\end{array}$ \\
\hline Control group & $\begin{array}{c}38 \\
(33.75-39.75) \\
\end{array}$ & $50.67 \pm 3.16$ & $9.99 \pm 1.74$ & $\begin{array}{c}14.11 \\
(12.78-14.64) \\
\end{array}$ \\
\hline GA group & $\begin{array}{c}37 \\
(35.25-39.5) \\
\end{array}$ & $50.42 \pm 3.04$ & $9.81 \pm 1.51$ & $\begin{array}{c}13.43 \\
(12.64-14.34) \\
\end{array}$ \\
\hline VTC group & $\begin{array}{c}36.5 \\
(32.25-42) \\
\end{array}$ & $50.12 \pm 3.73$ & $9.95 \pm 1.99$ & $\begin{array}{c}13.6 \\
(12.71-14.64) \\
\end{array}$ \\
\hline GA + VTC group & $\begin{array}{c}37 \\
(33.5-39.75) \\
\end{array}$ & $49.1 \pm 4.61$ & $9.6 \pm 1.76$ & $\begin{array}{c}14.09 \\
(12.86-14.57) \\
\end{array}$ \\
\hline AC group & $\begin{array}{c}95^{\text {abcd }} \\
(90-103.5) \\
\end{array}$ & $17.79^{\mathrm{abcd}} \pm 3.83$ & $2.64^{\mathrm{abcd}} \pm 1.03$ & $\begin{array}{c}0.075^{\mathrm{abcd}} \\
(0.06-0.09) \\
\end{array}$ \\
\hline AC+GA group & $\begin{array}{c}57.5^{\text {abcde }} \\
(50.75-61.75) \\
\end{array}$ & $30.26^{\text {abcde }} \pm 4.22$ & $6.49^{\text {abcde }} \pm 1.03$ & $\begin{array}{c}4.24^{\text {abcde }} \\
(3.44-5.52) \\
\end{array}$ \\
\hline VTC + AC group & $\begin{array}{c}56.5^{\text {abcde }} \\
(50.25-63.75) \\
\end{array}$ & $29.47^{\text {abcde }} \pm 2.47$ & $6.03^{\text {abcde }} \pm 1.0$ & $\begin{array}{c}4.24^{\text {abcde }} \\
(3.74-5.21) \\
\end{array}$ \\
\hline $\begin{array}{l}\text { GA +Vit C+ AC } \\
\text { group }\end{array}$ & $\begin{array}{c}46.5^{\text {abcdefg }}(40.25- \\
50.5)\end{array}$ & $41.69^{\text {abcdefg }} \pm 3.52$ & $7.73^{\text {abcdeg }} \pm 1.47$ & $\begin{array}{c}8.25^{\text {abcdefg }} \\
(7.21-9.43) \\
\end{array}$ \\
\hline Test & $\mathrm{KW}=49.78$ & $\mathrm{~F}$ test $=95.26$ & $F$ test $=25.0$ & $\mathrm{KW}=53.72$ \\
\hline$P$ value & $<0.001^{* *}$ & $<0.001 * *$ & $<0.001 * *$ & $<0.001 * *$ \\
\hline
\end{tabular}

$(* *)=$ Highly significant; IQR = Inter Quartile Range; KW: Kruskal-Wallis test; F test: ANOVA; GA= gallic acid; VTC= vitamin C; $\mathrm{AC}=$ Amoxicillin/clavulanic acid; MDA =malondialdehyde; GSH = reduced glutathione; GST= glutathione $\mathrm{S}$ transferase.

Different letter within the same row indicates significant differences $(\mathrm{p}<0.05)$ between experimental groups for the same blood and tissue chemical parameter; ${ }^{\mathrm{a}} \rightarrow$ difference versus control group; ${ }^{\mathrm{b}} \rightarrow$ difference versus GA group; ${ }^{\mathrm{c}} \rightarrow$ difference versus VTC group; ${ }^{\mathrm{d}} \rightarrow$ difference versus GA + VTC group; $\stackrel{\mathrm{e}}{\rightarrow} \rightarrow$ difference versus AC group; ${ }^{\mathrm{f}} \rightarrow$ difference versus AC + GA group; ${ }^{\mathrm{g}} \rightarrow$ difference versus AC.

Additionally, the present study documented a significant negative correlation significant positive correlation with (GSH and between HMOX-1 gene and MDA values and a

GST) among the studied groups (Table 3).

Table (3): Correlation between the Heme-oxygenase gene expression and each of MDA, GSH and GST among the studied groups.

\begin{tabular}{|l|c|c|c|c|c|c|}
\hline & \multicolumn{2}{|c|}{ Tissue MDA } & \multicolumn{2}{c|}{ Tissue GSH } & \multicolumn{3}{c|}{ Tissue GST } \\
\cline { 2 - 7 } & rho p & P value & rho & P vaue & rho p & P value \\
\hline $\begin{array}{l}\text { Heme-oxygenase gene } \\
\text { expression }\end{array}$ & -0.974 & $<0.001^{* *}$ & 0.843 & $<0.001^{* *}$ & 0.808 & $<0.001^{* *}$ \\
\hline
\end{tabular}

MDA =malondialdehyde; GSH = reduced glutathione; GST= glutathione S transferase; rho: Spearman's rank correlation coefficient 
Liver sections in negative control, GAtreated, VTC-treated and "GA + VTC"-treated groups (groups a, b, c and $\mathrm{d}$ respectively) illustrate normal lobular architecture with normal central vein and radiating cords of wellarranged polyhedral hepatocytes with rounded vesicular nuclei, separated by blood sinusoids as shown in (Figure 2).

However, the histopathological examination of hepatic tissue from rats in ACtreated group (group e) revealed markedly dilated central vein, severe congested dilatated sinusoids, cloudy swelling and necrotic hepatocytes along with pyknotic nuclei (Figure 3-a, b and c).

Co-administration of GA and /or VTC with $\mathrm{AC}$ in "AC + GA-treated" and "AC + VTC"-treated and "AC + GA + VTC"-treated group documented a hepatoprotective effect of GA and VTC where there was only dilated congested central vein and cloudy hepatocytes in group (f); and normal central and necroinflammatory hepatocytes in group (g). On other side sections of "AC + GA + VTC"treated group (group h) illustrated normal lobular architecture, normal central vein with minimal sinusoidal dilatation and in as shown in (Figures 4, 5 and 6 respectively).
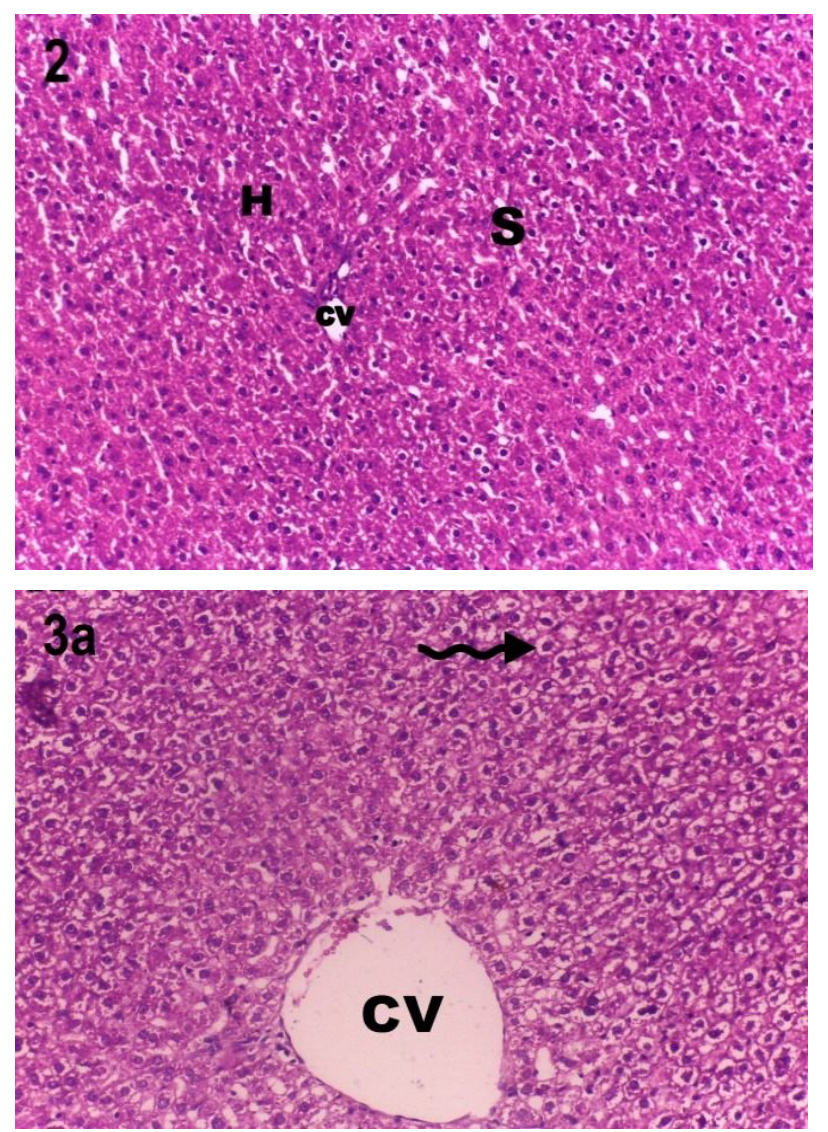

Fig. (2): A photomicrograph of a section in rat's liver prepared from a control rat showing normal architecture with well-arranged polyhedral hepatocytes contained rounded vesicular nuclei $(\mathbf{H})$ normal central vein $(\mathbf{C V})$ and normal sinusoids (S) (H\&E x 200).

Fig. (3a): A photomicrograph of a section in rat's liver prepared from $\mathrm{AC}$ treated group showing marked dilated central vein (CV) and cloudy swelling in hepatocytes (curved arrow) (H\&E x 200). 

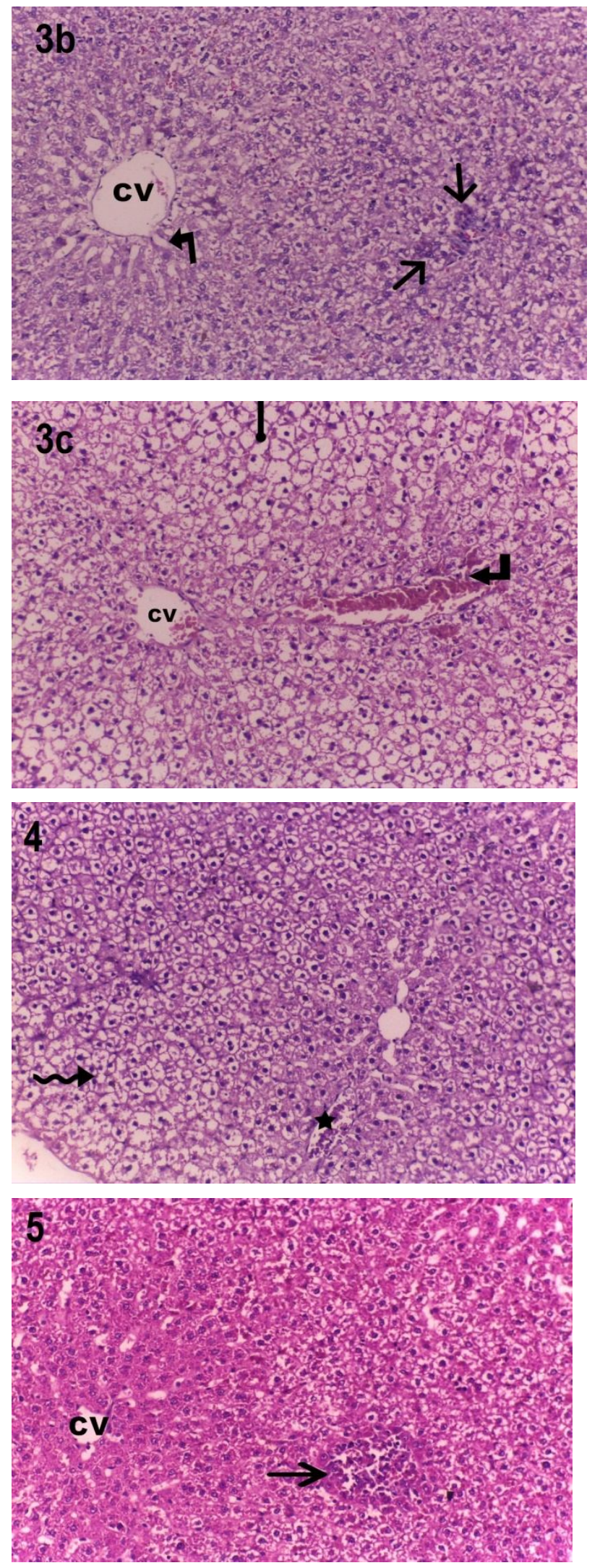

Fig. (3b): A photomicrograph of a section in rat's liver prepared from AC treated group showing dilated central vein $(\mathbf{C V})$, necrotic hepatocytes with pyknotic nuclei (straight arrows) and sever dilatation sinusoids (elbow arrows) (H\&E x 200).

Fig. (3c): A photomicrograph of a section in rat's liver prepared from AC treated group showing dilated congested central vein (CV) and sever congested dilated sinusoids (elbow arrows) with hydropic changes in hepatocytes (drum stick) (H\&E x 200).

Fig. (4): photomicrograph of a section in rat's liver prepared from $\mathrm{AC}+$ GA treated group showing dilated congested central vein (black star) and cloudy hepatocytes (curved arrow) (H\&E x 200).

Fig. (5): A photomicrograph of a section in rat's liver prepared from $\mathrm{AC}+$ VTC treated group showing normal central vein $(\mathbf{C V})$ and necro-inflammatory hepatocytes (straight arrows) (H\&E x 200). 


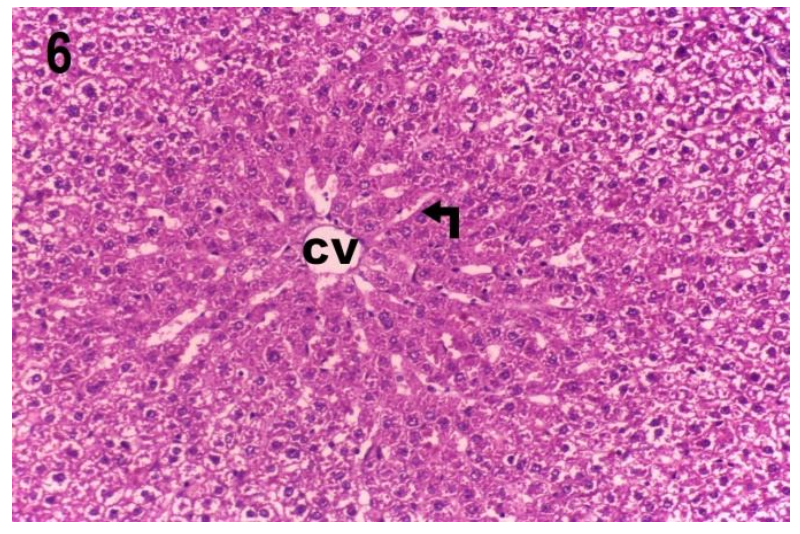

Fig. (6): A photomicrograph of a section in rat's liver prepared from AC + GA+ VTC treated group showing normal central vein $(\mathbf{C V})$ and moderate dilatation of sinusoids (elbow arrows) (H\&E x 200).

\section{Discussion}

The liver is an imperative central organ that plays a crucial role in the metabolism of many drugs and their reactive metabolites which render it not only the most important organ for detoxification, but also a major target for their toxicity as well (Ghabril et al., 2010; El-Hosseiny et al., 2016).

Amoxicillin, especially in combination with potassium clavulanate (AC), is a widely prescribed antibiotic to prevent and treat Gramnegative bacterial infections. However, many evidences documented that it is the most common drug in clinical medicine strongly associated with drug-induced hepatocellular damage and cholestatic liver injury (Stine and Chalasani, 2015; Yu et al., 2017 b).

The treatment of rats with gallic acid (GA) or vitamin C (VTC) alone or in combination did not illustrate any significant variation in the whole evaluated parameters when compared to non-treated control rats, so negative control group was chosen as a representative group to be compared with the biochemical and histopathological results of the rest of other treated groups.

Regarding liver function biochemical parameters, the findings of the current study documented a marked significant increase in Aspartate aminotransferase (AST) and Alanine aminotransferase (ALT) levels in serum of AC- treated group when compared with control and other studied groups. EL-Sherbiny et al. (2009) reported an excess activity of plasma AST and ALT on administration of combined AC+ Clavulanate $(50 \mathrm{mg} / \mathrm{kg}, 10 \mathrm{mg} / \mathrm{kg}$, respectively, orally for 21 days). Also, Olayinka et al. (2012) and El Shemy (2018) who treated rats with AC at a dose of $31.83 \mathrm{mg} / \mathrm{kg}$ body weight twice for seven days reported the same results.

The increased serum level of previously mentioned cytoplasmic hepatocyte enzymes might be due to excessive release of these enzymes into blood stream as a result of toxic effect of AC on liver cells. This cause disruption and damage of hepatocytes cell membranes, destruction and necrosis of hepatocytes. Additionally, the hepatic enzymes activity are probably raised due to significant increase in malondialdehyde (MDA) and reduction in reduced glutathione $(\mathrm{GSH})$ and glutathione -S- transferase (GST) concentration at the $\mathrm{AC}$ treated group.These are considered the first line defense in scavenging the free radicals (Gumieniczek, 2005; Sahib et al., 2016).

Tumor necrosis factor alpha (TNF- $\alpha$ ) is a well characterized major inflammatory cytokine developed by macrophages/ monocytes during acute inflammation and is responsible for inflammation that plays a role in liver injury (Santos et al., 2015). It is the 
first multifunctional cytokine generated from monocytes and macrophages during trauma or infection which can do the inflammatory cascade and share in exacerbating liver injury. It has been noticed that drug exposure during periods of inflammation can increase susceptibility of human's toxicity (Maruf and O'Brien, 2014; Kim et al., 2015; Yao et al., 2016).

In the current study, tumor necrosis factor alpha (TNF- $\alpha$ ) activity was significantly increased in AC treatment group when compared to other groups that agreed with the previous results obtained by (Yu et al., $2017 \mathrm{~b}$; El Shemy, 2018). Furthermore, Dufour and Meillet (2005) stated that Augmentin administration induces $\mathrm{TNF}-\alpha$ release by cytotoxic T-lymphocytes, natural killer cells and monocytes.

Apoptosis is a state of programmed cell death that occurs under both physiological and pathological situations. However, it was found that free radicals-produced oxidative stress can attack the membrane phospholipids in mitochondria, this leads to loss of mitochondrial membrane potential causing the release of intermembrane proteins, such as cytochrome $\mathrm{c}$, to the cytoplasm which can trigger caspase-3 activation leading to cell apoptosis (Li et al., 2006).

In the present study, oral intake of $\mathrm{AC}$ produced marked significant increase in caspase -3 level as compared to the control and other treated groups. Current finding of induction of apoptosis by $\mathrm{AC}$ is consistent with previously published studies by El-Kholy et al. (2019) who documented marked increases in the apoptotic markers caspase- 3 in the liver of treated rats with oral administration of AC (30 and $60 \mathrm{mg} / \mathrm{kg}$ ) and this apoptotic effect of the drug was found to be dose-dependent. Amoxicillin/ Clavulanic acid triggered apoptosis is related to the overproduction oxidative reactive molecules along with a reduction in antioxidant GSH and GST (Yu et al., 2017a).

Lipid peroxidation is an accurate indicative parameter for reactive oxygen species (ROS) created systemic injury (Georgieva et al., 2006). Malondialdehyde is recognized as one of the last products of lipid peroxidation. Its level is generally known as the marker of antioxidant status and oxidative stress (Tsikas et al., 2016; Yu et al., 2017 b). Glutathione S-transferase is a highly diverse family of enzymes which protect against the breakdown products of macromolecules during oxidative stress. GSH supply the cell with multitude of defenses against reactive oxygen species and toxic products. In fact, GSH a major reductant in cells, can reduce a wide variety of disulfides by trans-hydrogenation, and is an important ROS scavenger (Lee et al., 2010).

The current study documented a highly significant increase in MDA concentrations in $\mathrm{AC}$ group and a significant reduction of reduced GSH and GST at the same group as compared with other studied groups. The increased production of free radicals MDA accompanied with reduction of the detoxifying capability of the liver (reduction of GSH and GST) in the present study could be attributed to oxidative damage to vital molecules in the cells which leads to the destruction of cell membranes with subsequent release of biomarkers of liver injury. Several previous studies have linked disturbance in the balance between lipid peroxidation by-products; MDA and antioxidant parameter; in $\mathrm{AC}$ administration to deleterious hepatotoxic effects. El-Sherbiny et al. (2009) announced that $\mathrm{AC}$ or clavulanic acid administration and their combination resulted in a pronounced elevation of the oxidative stress marker as demonstrated by increased lipid peroxidation MDA and depletion of antioxidant molecules such as GSH. Additionally, El-Kholy et al. 
(2019) revealed that AC in a drug dosedependent reduced the hepatic levels of antioxidant molecules including GSH. Also, findings by Olayinka et al. (2012); Delemos et al. (2016); Sahib et al. (2016); Yu et al. (2017a) and El Shemy (2018) were in line with the current work.

Inducible heme oxygenase gene $(\mathrm{HO})$ subtype inducible heme oxygenase gene -1 (HMOX-1) is a key protective molecule in mammalian cells. It is able to relieve acute and chronic liver injury due to its characteristic anti-inflammatory and anti-apoptotic characters, and may be useful as a new strategy of alleviating this type of damage ( $\mathrm{Li}$ et al., 2019). In cases of inflammation and apoptosis, HO-1 overexpression is one of the protective mechanisms for activation in tissues and organs (Mylroie et al., 2015; Wei et al., 2018). It is also involved in maintaining the balance of antioxidants and oxidants in the process of cell damage (An and Shang, 2018; Deng et al., 2018). The results of our study illustrated that acute $\mathrm{AC}$ exposure leading to a significant inhibition of HMOX1 gene expression compared to other studied rat's groups. In contrast, concomitant administration of GA and VTC either individually or in combination with AC caused a highly significant upregulation in HMOX1 gene expression with best results obtained when GA and VTC used in combination which probably is due to synergistic effect.

Additionally, we observed the presence of a highly significant negative correlation between HMOX1 gene expression and MDA. So, there was a highly significant positive correlation between HMOX1 gene expression and both antioxidant parameter (GSH and GST) which could be explained by the fact that the induction of HMOX1 is well-formed as a cytoprotective response to liver injury by suppressing oxidative stress, inflammation and reducing apoptotic hepatic damage (Gao et al.,
2017). Yao et al. (2007) documented inhibition in HMOX1 gene expression due to chronic ethanol administration. Also, Kyokane et al. (2001); Dorman et al. (2004) reported that over-expression of HO-1 has been illustrated to be protective against endotoxin mediated hepatic dysfunction. Additionally, stimulation of HO-1 has recently been demonstrated as a defense of human hepatocytes against hypoxia, suggesting that HO-1 induction may have a potential therapeutic effect against inflammatory attacks (Tüzüner et al., 2004).

In this line, Omobowale et al., (2017) found that rats' treatment with GA at a dose of (60 $\mathrm{mg} / \mathrm{kg}$ body weight orally for 7 days) produced hepatoprotective effect against hepatic damage in Doxorubicin cancer chemotherapy. Furthermore, Oyagbemi et al. (2016) concluded that GA treatment reverses the oxidative stress by enhancing the antioxidant defense system and preventing lipid peroxidation (LPO) and therefore, speculate that the inherent antioxidant property of this compound is responsible for its hepatoprotective effect against cyclophosphamide-induced toxicity. Also, results of the study by Safaei et al. (2018) proposed that oral GA may protect liver tissue from oxidative damages induced by methotrexate by altering the activity of antioxidant enzymes and antioxidant levels. Direct or indirect antioxidant properties of GA can decrease oxidative stress-induced injuries in liver tissue exposed to methotrexate.

Ascorbic acid (vitamin C) represents the first line of antioxidant defense, and this vitamin is likely to be most susceptible to free radical oxidation. It is a strong free radical scavenger as a result of its chemical characters (Olayinka and Olukowade, 2010). In accordance with our study, Abdulkhaleq et al. (2018) reported that pretreatment with vitamin $\mathrm{C}$ has been found to be beneficial in hepatic oxidative stress prevention induced by 
paracetamol overdose. Moreover, Farombi and Onyema, (2006) documented that VTC ameliorates oxidative stress induced by monosodium glutamate.

The results of our study indicated that GA and VTC possess a powerful anti-inflammatory substance that reverses the inflammatory effects of $\mathrm{AC}$ as they reduce the production of pro-inflammatory cytokines. Also, their effects on oxidant markers can lead to a clear improvement in oxidative stress.

In line with the biochemical results, the histopathological evaluation of hepatic sections of rats treated with $\mathrm{AC}$ showed marked dilatation and congestion in central vein and sinusoids along with hydropic changes, cloudy swelling and necrotic hepatocytes with pyknotic nuclei. These findings are in agreement with many studies; Sahib et al. (2016) revealed that $\mathrm{AC}$ administered orally (0 $2.232 \mathrm{mg} / \mathrm{kg}$, three times/day for 7 days) in adult albino rats resulted in hepatocyte necrosis, central vein enlargement with subsequent hemorrhage and congestion, in addition to the accumulation of many inflammatory cells. El-Hosseiny et al. (2016) demonstrated that a rat model exposed to Coamoxiclav (30 mg/kg body weight, orally for 7 days) exhibited provoked histoarchitectural changes manifested by hydropic changes, central vein necrosis and congestion, as well as, mild inflammatory and cholestatic changes. Also, El Shemy (2018) concluded that male rats treated daily with $\mathrm{AC}$ at a dose of 31.83 $\mathrm{mg} / \mathrm{kg}$ b. wt twice for seven days orally resulted in ballooning degeneration and hepatic damage. Moreover, the study by Khan et al. (2018) documented acute cellular swelling and vacuolar degeneration with mild coagulative necrosis of hepatocytes.

The histopathological changes in AC treated group occurred due to lipid peroxidation which inducing disruption in membrane lipids of hepatocyte, with continuous rise in free radicals production. In contrast, the addition of GA and VTC both individually or with each other in conjunction with AC leads to improvement and reverse these findings to some extent.

\section{Conclusions}

The current study provided additional evidence that combined Amoxicillin / clavulanate (AC) could be associated with a potential risk of hepatotoxicity. Moreover, synchronous administration of gallic acid (GA) and vitamin C (VTC) either alone or in combination along with $\mathrm{AC}$ exerted beneficial effects in the protection against $\mathrm{AC}$-induced inflammation, oxidative stress and hepatic damage in albino rats. These could be largely attributed to their potent anti-inflammatory effects and their ability to improve and activate antioxidant defense mechanisms.

\section{Recommendations}

Based on the results of the current study, it's recommended that:

1- The used of Amoxicillin/Clavulanic acid should be under the observation of physicians along with monitoring of diagnostic markers of liver injury in the blood. Furthermore, decrease of its use even in the therapeutic doses especially in high risk and vulnerable groups.

2- Administration of vitamin $\mathrm{C}$ and gallic acid with Amoxicillin/Clavulanic acid have considerable protective effects against AC-induced hepatic toxicity.

3- Additional studies on the cytoprotective role of HMOX-1 gene to be used as a new therapeutic line against drugs induced hepatic toxicity. 


\section{Acknowledgment}

Our deep gratitude and appreciation to staff members of Forensic Medicine and Clinical Toxicology, Biochemistry and Pathology Departments, Faculty of Medicine, Banha University, for their cooperation.

\section{References}

Abdulkhaleq, F.M.; Alhussainy, T.M.; Badr, M.M.; et al. (2018): "Antioxidative stress effects of vitamins $\mathrm{C}, \mathrm{E}$, and $\mathrm{B} 12$, and their combination can protect the liver against acetaminophen - induced hepato toxicity in rats". Drug Des. Devel. Ther., 12: 3525-3533.

An, X. and Shang, F. (2018): "RA-XII exerts anti-oxidant and anti-inflammatory activities on lipopolysaccharide-induced acute renal injury by suppressing NFkappa B and MAPKs regulated by HO1/Nrf2 pathway". Biochem. Biophys. Res. Commun., 495(3): 2317-2323.

Bancroft, J.D. and Layton, C. (2019): "The hematoxylins and eosin. In: Bancroft's theory and practice of histological techniques", (ELSEVIER, China). By: Suvarna, S.K., Layton, C. and Bancroft J.D. (eds.), 8th ed., Chapter (10), P.P. 126-183.

Chaphalkar, R., Apte, K. G., Talekar, Y., et al. (2017): "Antioxidants of Phyllanthus emblica L. Bark Extract Provide Hepatoprotection against Ethanol-Induced Hepatic Damage: A Comparison with Silymarin". Oxid. Med. Cell Longev., 2: 3876040 .

Delemos, A.S.; Ghabril, M.; Rockey, D.C.; et al. (2016): "AmoxicillinClavulanateInduced liver injury". Dig. Dis. Sci., 61 (8): 2406-2416.
Deng, C.; Cao, J.; Han, J.; et al. (2018): "Liraglutide activates the Nrf2/HO-1 antioxidant pathway and protects brain nerve cells against cerebral ischemia in diabetic rats". Comput. Intell. Neurosci., 1: 3094504.

Devarbhavi, H., and Andrade, R.G. (2014): "Drug-induced liver injury due to antimicrobials central nervous system agents, and nonsteroidal antiinflammatory drugs". Semin. Liver Dis., 34: 145-161.

Dorman, R. B.; Bajt, M. L.; Farhood, A.; et al. (2004): "Heme oxygenase-1 induction in hepatocytes and non-parenchymal cells protects against liver injury during endotoxemia". Comp. Hepatol., 3: 42.

Dufour, V. and Meillet, D. (2005): "Effects of a short-course of amoxicillin/clavulanic acid on systemic and mucosal immunity in healthy adult humans". Inter. Immunopharma., 5 (5): 917-928.

EI Shemy, M. A. (2018): "Protective effects of curcumin against Augmentin-induced hepatotoxicity in rats". Benha Vet. Med. J., 35(1): 375-386.

El-Hosseiny, L.S.; Alqurashy, N.N. and Sheweita, S.A. (2016): "Oxidative Stress Alleviation by Sage Essential Oil in Coamoxiclav induced Hepatotoxicity in Rats". Int. J. Biomed. Sci., 12 (2): 71-78.

El-Kholy, M.W.; Faried, A.E. and Ghada, M.E. (2019): "Role of Cinnamon extract in the protection against Amoxicillin/ clavulanate-induced liver damage in rats". I.O.S.R.-J.P.B.S., 14 (1): 14-21.

El-Sherbiny, G.A.; Taye, A. and Raheem, I.T.A. (2009): "Role of ursodeoxycholic acid in prevention of hepatotoxicity caused by amoxicillin-clavulanic acid in rats". Ani. Hepat., 8 (2): 134-140.

Farombi, E.O. and Onyema, O.O. (2006): "Monosodium glutamate - induced 
oxidative damage and genotoxicity in the rat: modulatory role of vitamin $\mathrm{C}$, vitamin $\mathrm{E}$ and quercetin". Hum. Exp. Toxicol., 25 (5): 251-259.

Gao, Y.; Cao, Z.; Yang, X.; et al. (2017): "Proteomic analysis of acetaminopheninduced hepatotoxicity and identification of heme oxygenase -1 as a potential plasma biomarker of liver injury". Proteomics Clin., 11 (1-2):11.

Georgieva, N.V.; Koinarski, B. and Gadjeva, V. (2006): "Antioxidant status during the course of Eimeria tenella infection in broiler chickens". Vet. J., 172 (3): 488492.

Ghabril, M.; Chalasani, N. and Bjornsson, E. (2010): "Drug-induced liver injury: a clinical update". Curr. Opin. Gastroenterol., 26: 222-226.

Guillermo, O.; Noriega, A.; Jorge, O.; et al. (2000): "Batlle Effect of acetaminophen on heme metabolism in rat liver". INT. J. BIO., 32: 983-991.

Gumieniczek, A. (2005): "Oxidative stress in kidney and liver of alloxan induced diabetic rabbits: effect of repaglini de". Acta. Diabetol., 42(2): 75-81.

Jacob, R.A. and Sotoudeh, G. (2002): "Vitamin $\mathrm{C}$ function and status in chronic disease". Nutr. Clinic. Care, 5: 66-74.

Khan, M.; Sarkar, U. and Mandal, T. (2018): "Effect of amoxicillin on haematobiochemical parameters in poultry". Inter. J. Livestock Res., 8(4):1.

Kim, S.H.; Saide, K.; Farrell, J.; et al. (2015): "Characterization of amoxicillinand clavulanic acid-specific $\mathrm{T}$ cells in patients with amoxicillin/clavulanateinduced liver injury". Hepatol., 65:887899.
Kyokane, T.; Norimizu, S.; Taniai, H.; et al. (2001): "Carbon monoxide from heme catabolism protects against hepatobiliary dysfunction in endotoxin-treated rat liver". Gastroenterol., 120: 1227-1240.

Lee, M.Y.; Lee, N.H.; Seo, C.S.; et al. (2010): "Shin-Alpinia katsumadai seed extract attenuate oxidative stress and asthmatic activity in a mouse model of allergic asthma". Food Chem. Toxicol., 48: 17461752.

Leitner, J.M.; Graninger, W. and Thalhammer F. (2010): "Hepatotoxicity of antibacterials: Pathomechanisms and clinical". Infect., 38: 3-11.

Li, J.; Tang, Q. and Li, Y. (2006): "Role of oxidative stress in the apoptosis of hepatocellular carcinoma induced by combination of arsenic trioxide and ascorbic acid". Acta. Pharmacol. Sin., 27: 1078-1084.

Li, S.; Fujino, M.; Takahara, T. et al. (2019): "Protective role of heme oxygenase-1 in fatty liver ischemiareperfusion injury". Med. Mol. Morphol., 52 (2): 61-72.

Maruf, A.A. and O'Brien, P. (2014): "Inflammation-enhanced drug-induced liver injury". Free Radic. Biol. Med., 1: 40.

Mylroie, H.; Dumont, O.; Bauer, A.; et al. (2015): "PKCepsilon -CREB -Nrf2 signalling induces HO-1 in the vascular endothelium and enhances resistance to inflammation and apoptosis". Cardiovasc. Res., 106 (3): 509-519.

Olayinka, E.T. and Olukowade, I. L. (2010): "Effect of amoxycillin/clavulanic acid (Augmentin 625®) on antioxidant indices and markers of renal and hepatic damage in rats". J. Toxicol. Enviro. Health Sci., 2 (6): 85-92. 
Olayinka, E.T.; Olukowade, I. and Oyediran, O. (2012): "Amoxycillin/ clavulanic acid combinations (Augmentin 375 and 625 tablets) induced oxidative stress, and renal and hepatic damage in rats". African J. Pharmac., 6: 2441-2449.

Omobowale, T.O.; Oyagbemi, A. A.; Ajufo, U. E.; et al. (2017): "Ameliorative Effect of Gallic Acid in Doxorubicin-Induced Hepatotoxicity in Wistar Rats through Antioxidant Defense System". J. Diet Suppl., 15 (2): 183-196.

Oyagbemi, A.A.; Omobowale, O.T.; Asenuga, E.R.; et al. (2016): "Cyclophosphamide-induced hepatotoxicity in wistar rats: the modulatory role of gallic acid as a hepatoprotective and chemopreventive phytochemical". Int. J. Prev. Med., 7:51.

Priscilla, D.H. and Prince, P.S. (2009): "Cardioprotective effect of gallic acid on cardiac troponin- $\mathrm{T}$, cardiac marker enzymes, lipid peroxidation products and antioxidants in experimentally induced myocardial infarction in Wistar rats". Chem. Biol. Interact., 179 (2-3):118-124.

Safaei, F., Mehrzadi, S.; Khadem Haghighian, H.; et al. (2018): "Protective effects of gallic acid against methotrexateinduced toxicity in rats". Acta. Chir. Belg., 118 (3): 152-160.

Sahib, A.M.; Jwad, S.M. and Taha, T.M. (2016): "Study the protection effect of alcoholic extract of Iraqi propolis on some of liver and kidney functions at male albino rats administered with a combination of amoxicillin/clavulanic acid (augmentin) antibiotic". I.J.B.P.A.S., 5 (6): 1418-1454.

Santos, J.C.; de Araújo, O.R.; Valentim, I.B.; et al. (2015): "Choline and cystine deficient diets in animal models with hepatocellular injury: evaluation of oxidative stress and expression of RAGE, TNF- $\alpha$, and IL-1 $\beta "$. Oxid. Med. Cell Longev., 2:1-11.

Seghrouchni, I.; Drai, J.; E. Bannier, E.; J. et al. (2002): "Oxidative stress parameters in type 1 , type 2 and insulin-retreated type 2 diabetes mellitus: Insulin treatment efficiency". Clin. Chim. Acta., 321 (1-2): 89-96.

Stine, J.G. and Chalasani. N. (2015): "Chronic liver injury induced by drugs: a systematic review". Liver Int., 35 (11): 2343-2353.

Tsikas, D.; Rothmann, S.; Schneider, J.Y.; et al. (2016): "Development, validation and biomedical applications of stableisotope dilution GC-MS and GC-MS/MS techniques for circulating malondialdehyde (MDA) after penta fluorobenzyl bromide derivatization: MDA as a biomarker of oxidative stress and its relation to 15(S)-8-isoprostaglandin F2 $\alpha$ and nitric oxide". J. Chromatogr., 1019: 95-111.

Tüzüner, E.; Liu, L.; Shimada, M.; et al. (2004): "Heme oxygenase-1 protects human hepatocytes in vitro against warm and cold hypoxia". J. Hepatol., 41(5):764772.

Wei, W.; Shurui, C.; Zipeng, Z.; et al. (2018): "Aspirin suppresses neuronal apoptosis, reduces tissue inflammation, and restrains astrocyte activation by activating the Nrf2/HO-1 signaling pathway". Neuroreport., 29 (7): 524-531.

White, A.R.; Kaye, C.; Poupard, J.; et al. (2004): "Augmentin $\AA$ (amoxicillin/ clavulanate) in the treatment of community-acquired respiratory tract infection: a review of the continuing development of an innovative antimicrobial agent". J. Antimicrob. Chemother., 53: 3-20. 
Yao, B.; Li, k.; Song, F.; et al. (2007): "Heme oxygenase -1 upregulated by Ginkgo biloba extract: Potential protection against ethanol - induced oxidative liver damage". Food Chem. Toxicol., 45:1333-1342.

Yao, H.; Hu, C.; Yin, L.; et al. (2016): "Dioscin reduces lipopolysaccharide induced inflammatory liver injury via regulating TLR4/MyD88 signal pathway". Int. Immunopharmacol., 36:132-141.
Yu, Z.; Guo, F.; Zhang, Z.; et al. (2017 a): "Protective effects of glycyrrhizin on LPS and amoxicillin/potassium clavulanateinduced liver injury in chicken". Pak. Vet. J., 37(1): 13-18.

Yu, Z.; Wu, F.; Tian, J.; et al. (2017 b): "Ammonium glycyrrhetate counteracts liver injury caused by lipopolysaccharide/ amoxicillin-clavulanate potassium". Oncotarget., 8 (57): 96837-96851. 


\title{
الدور المعدل لحمض الجاليك وفيتامين سي المجموعة الاموكسيسيلين/ حمض الكالفولنيك المسبب لتسمم الكبد في الجرذان البيضاي البالغة
}

\author{
أسماء يس عبد الخالق حسين'، سنية عليوه' ، شيماء عبد الرحمن '، هايلدي محمد فخر ' \\ ' قسم الطب الثرعي و السموم الاكلينكية، كلية الطب ، جامعة بنها، مصر

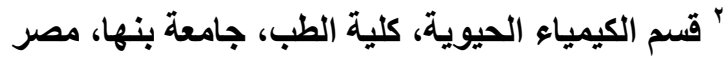

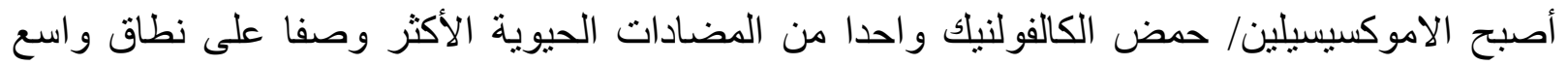

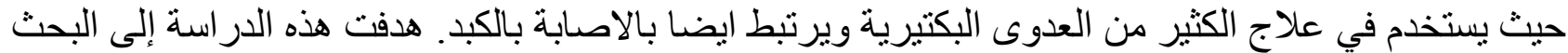

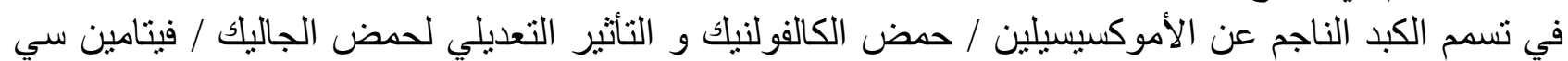
بشكل فردي ومجتمعيين على تلف الكبد الناتج عن الإكسدة. تم فصل أربعة وستين ذكور من الجرذان البيضاء بشكل عشو ائي إلى ثماني مجمو عات: مجمو عة سلبية ضابطة، مجمو عة حمض الجاليك ، مجمو عة فيتامين سي، مجمو عة حمض الجاليك و فيتامين سي، مجمو عة الاموكسيسيلين/ حمض الكالفولنيك، مجمو عة الاموكسيسيلين/

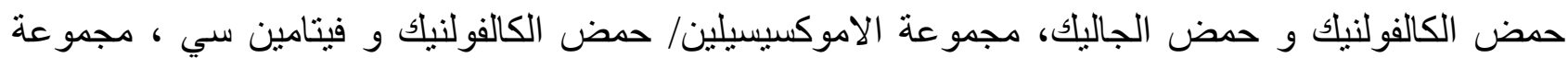
الاموكسيسيلين/ حمض الكالفولنيك و حمض الجاليك و فيتامين سي. تم إعطاء الجرذان جر عة مرتين يوميًا من

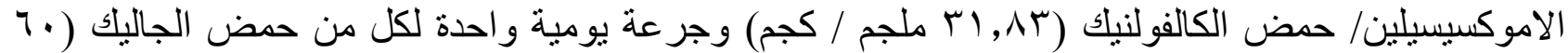

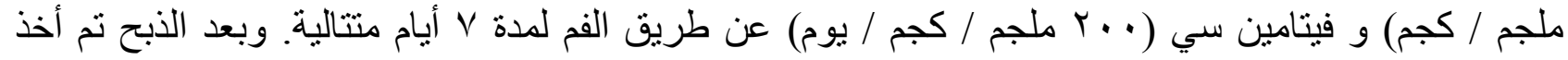

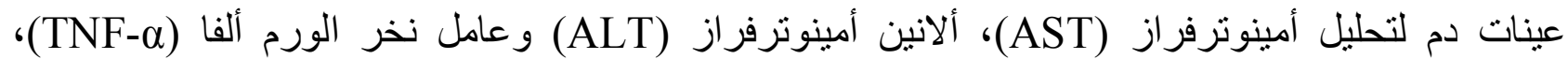

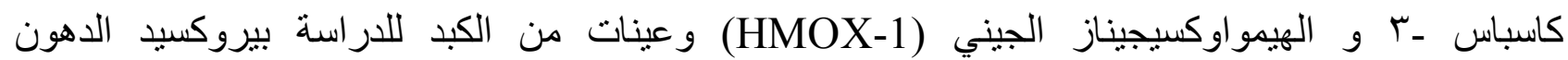
و الهستوباتولوجية. يتضح وجود زيادة ذو دلالة احصائية عالية في مستويات TNF-

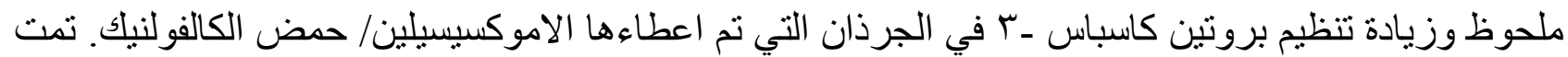
زيادة المحتويات الكبديّة للمالونديالديهايد (MDA) بشكل ملحوظ بعد تناول الاموكسيسيلين/ حمض الكالفولنيك،

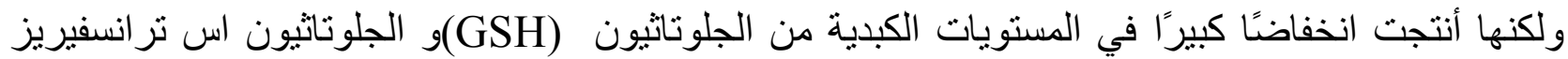
وكذلك جنبًا إلى جنب مع التعبير المنتظم عن (GST)

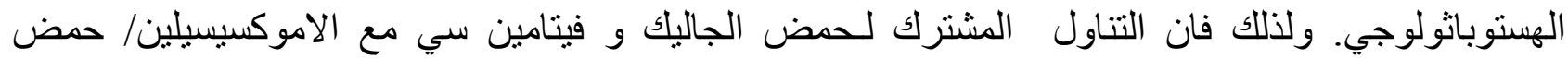

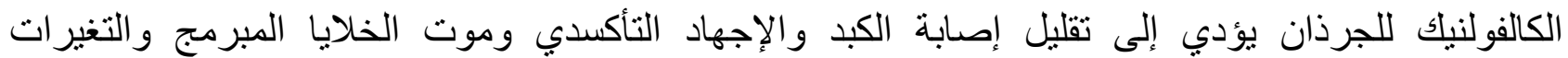
الهستوباتولوجية. 